operation whereby the British Islands were isolated. We must not forget however that denudation also played its part. The excavation of the Strait of Dover, for example, may have been in large measure effected by streams diverging from the watershed and partly by the littoral erosion of the waves as they advanced upon the slowly foundering land. The recent date of the separation of Britain is shown by the identity of the fauna as a whole with that of France and Germany. But as compared with the continent, the British Isles are remarkably poor in species. In Germany, for example, there are nearly ninety species of land mammals; even Scandinavia possesses about sixty; but Britain can boast only forty--a number which in Ireland is reduced to twenty-two. Still more remarkable is the contrast presented by the reptiles and amphibia; for while Belgium possesses twenty-two species, Britain can show no more than thirteen, and Ireland has only four. This progressive diminution of the fauna westward is even illustrated by animals possessing the power of flight, though, as might be supposed, it is in these cases less strongly marked. The twelve bats of Britain are reduced to seven in Ireland, the 130 land-birds to about IIO. In Britain 1425 species of flowering plants and ferns are known, but in Ireland only 970 , or two-thirds of the British flora. The reason assigned by $\mathrm{Mr}$. Wallace for this poverty of species is the extensive submergence of the British Islands during the later stages of the Glacial Period. He believes that the interval between the subsequent elevation and the final separation of Britain from the continent cannot have been of long duration. It was indeed sufficiently prolonged to allow of the migration westwards of a considerable part of the Post-glacial fatna and flora, but the insular condition was established before more than a part had succeeded in reaching Britain, where both the soil and climate would have been eminently favourable for the reception of the rest. The time that has elapsed since our area ceased to be continental has been long enough for the production of a few peculiar varieties. No distinct species or variety of mammal, reptile, or amphibian has arisen. But we possess three peculiar birds-the coal-tit, long-tailed tit, and grouse-fifteen peculiar species of fresh-water fishes, sixty-nine lepidopterous insects, seventy-two beetles, four caddis-flies, and four terrestrial and fluviatile shells believed to be peculiar. In the flora the chief contrasts are exhibited by the mosses and hepaticæ, of which respectively seventeen and nine forms appear to be peculiar. This mode of considering the British fauna and flora brings out in clear relief the relations between them and those of the continent, and their bearings upon the question of the origin of peculiar forms. Not only do the British Islands as a whole contain species or varieties that do not appear on the mainland of Europe, but some of our outlying islands, such as the Shetland Isles, the Isle of Man, and Lundy Island, possess each its local forms that are not met with on the main island.

As "anomalous islands" the author classes together Celebes and New Zealand, the former because it belongs to no one of the six zoological regions of the globe, and cannot be certainly affirmed to have been united to a continent, the latter because in some respects it may be regarded as an oceanic, in others as a continental island. Celebes is supposed by Mr. Wallace to be probably a fragment of Miocene Asia, preserving down to the present time a few remnants of its Tertiary fauna, together with an intermixture of more modern types that have been introduced by ordinary means of dispersal. Three interesting chapters are devoted to New Zealand, and in these is discussed the important question of the origin of the European element in the floras of the temperate southern latitudes.

Enough has been said here to show the nature and value of this new contribution to scientific literature. Even where Mr. Wallace's conclusions may be disputed, they are always of the most suggestive kind. His volume, as he acknowledges, is the development and application of a theory; but it is not written in the spirit of a mere partisan. Its facts are of course marshalled in such form as most effectively to sustain the theory; yet with a transparent directness and honesty of purpose that runs through the whole book, and gives it one of its great charms. The writer does not consciously shut his eyes to any of the difficulties of his case. Candidly admitting them, he presents such explanation as seems to him to offer the most likely pathway to their ultimate solution.

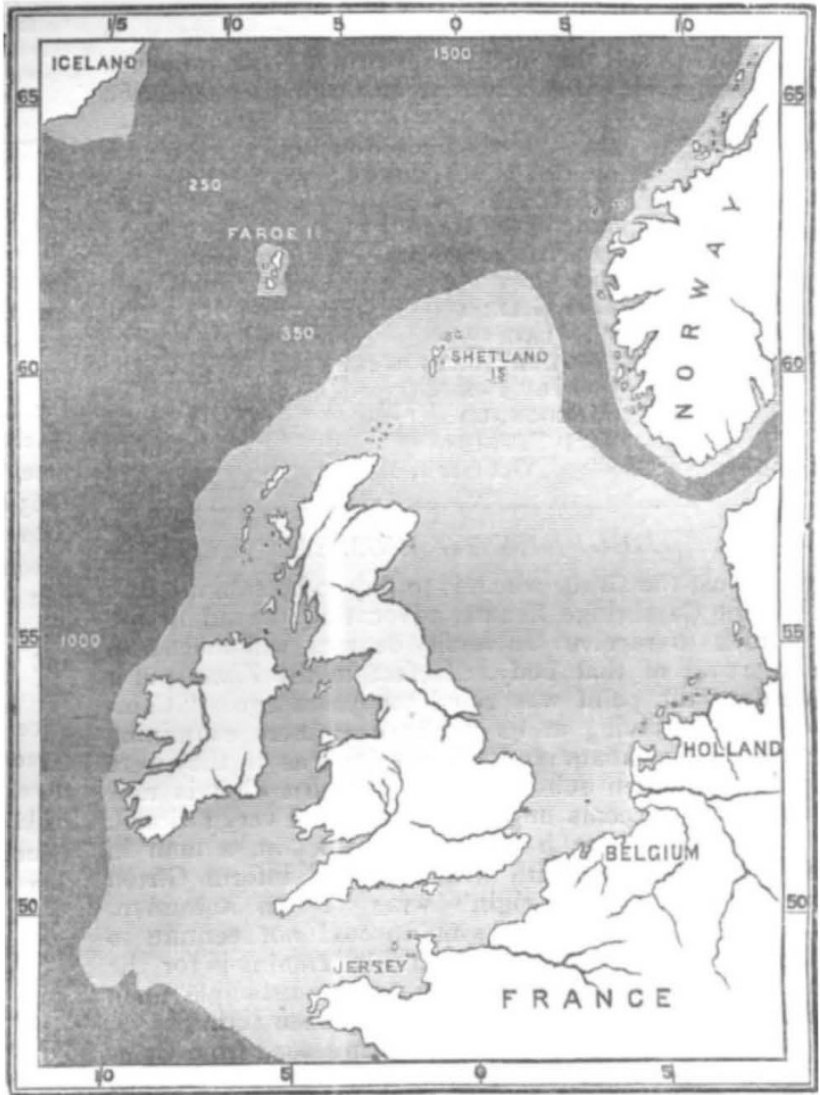

IG. 2.-Map of the shallow bank connecting the British Isles with the Continent. The dark tint marks sea of more than, the paler tint shows sea of less than, rooo fathoms n depth. The figures show the depth in fathoms. The narrow channel between Norway and Denmark is 2580 feet deep.

He deserves the thanks alike of geologists and of biologists for a treatise, the appearance of which marks another epoch in the history of the doctrine of Evolution.

ARCH. TEIKIE

\section{HONOUR TO MR. DARWIN}

THE following address to Mr. Darwin, from New Zealand, speaks for itself :-

\section{To Charles Darwin, Esq.}

SIR,-We, the members of the Council of the Otago Institute, beg to offer you our congratulations on this, the 
twenty-first anniversary of the publication of your great work, the "Origin of Species."

However limited the field of our own labours may be, we cannot but be sensible of the influence which that work has had throughout the whole domain of Natural Science, and especially upon Biology, which, as one great comprehensive Science, may be said to owe its very existence to the fact that you made belief in Evolution possible by your theory of Natural Selection.

We are glad to think that you have lived to see the almost universal acceptance of the great doctrine which it has been the work of your life to establish ; it is hardly an exaggeration to say that every important Botanical or Zoological discovery of the last twenty-one years, particularly in the departments of Embryology and Palæontology, has tended to fill up some gap in the evidence you had originally collected, and to make Evolution no longer a theory, but an established doctrine of Science.

We hope that you may long live to continue your labours and to see the further spread of their influence upon all scientific thought and upon all higher scientific work.

We are, sir, your obedient servants, THOS. MORGAN HOCKER F. W. HutToN

GEORGE H. F. ULRICH GEORGE M. THOMSON HENRY SKEY Robert Gillies C. W. BlAIR ALEXANDER MONTGOMERY T. JEFFERY PARKER W. MACDONALD

Dunedin, New Zealand, October I, 1880.

partiality if it bars its doors, like a monastery, to female appli. cants for admission. 4. Because one of the legitimate wants and aspirations of the University-leisure for continued study and research-is likely to be promoted by increasing the amount of remunerative educational work done in the university. The more work, the more workers, and the more remuneration; and out of work, workers, and earnin ${ }_{0} \mathrm{~s}$, the legitimate and sure outcome will be leisure for the worthiest work and workers. 5. Because the education of women in England must, from irresistible national feelings and convictions, be religious and Christian; and if female education is centred in the university a stimulus will be given to the best religious influences in study and life; and from these the English universities have never for any long period been dissociated. 6. Because any mischievous consequences that might be feared, whether to the university or to the students, by the admission of women can be guarded against by suitable regulations, and still more by responsible authorities; whereas the diversion of the interests and influences that are gathering round the question of women's education from the university to other centres would be an irretrievable step, isolating the university for the future from a movement of great force and promise. J. L. BRERETON

February 16

\section{NOTES}

AT the anniversary meeting of the Royal Astronomical Society, on the I Ith inst., Mr. Hind, president, in the chair, the gold medal was presented to Prof. Axel Möller, Director of the Observatory at Lund, in Sweden, for his investigations on the motion of Faye's comet. Prof. Möller's researches commenced in 1860 , soon after attention had been directed to this cumet by the offer of a prize for the accurate determination of its orbit by the Society of Natural Sciences of Dantzic, and they have been continued to the present time, the comet's track at each of the three subsequent returns in $1865-66,1873$, and $1880-81$, having been predicted with a precision which has excited in no small degree the admiration of astronomers ; indeed, at the re-appearance in I 873 , M. Stephan's first observation at the Observatory of Marseilles, showed that the error of predicted place was less than six seconds of arc, and after the last revolution, when the perturbations from the action of the planets were greater than in any previous revolution since the comet was first detected by M. Faye in 1843 , the agreement between observation and calculation was still very close. One important result of these investigations has been a striking confirmation, from the motion of Faye's comet, of the value for the mass of Jupiter deduced by Bessel from the elonga. tions of the satellites, the two values according within the limits of their probable errors. Prof. Möller also carried back the accurate computation of the perturbations to December, 1838 , so as to ascertain the effect of a pretty near approach to Jupiter in March, 1841, upon the previous orbit, and having done this he examined the probable circumstances of a very near approach of the two bodies near the passage of the node in 1816 , to which attention had been drawn by Valz soon after the comet's orbit was fairly determined. Thus Möller's laborious investigations extend over a period of forty-three years, during which he has followed the motion of the comet with all the refinements of which the actual state of the science admits. It will be generally accorded that the medal has been well earned in Prof. Möller's case. The last occasion on which it was awarded for investigations of a similar kind was as far back as 1837 , when the Astronomer-Royal presented the medal to Rosenberger for his researches on the motion of Halley's comet.

Ar the anniversary of the Geological Society on Friday the medals were awarded as follows :-The Wollaston medal to Prof. P. Martin Duncan, M.B., F.R.S., F.G.S. ; the Murchison medal to Prof. Archibald Geikie, F.R.S., F.G.S.; the Lyell medal to Principal Dawson, LL.D., F.R.S., F.G.S., of McGill College, Montreal ; and the Bigsby medal to Dr. Charles Barrois of Lille. The Wollaston Fund was awarded to Dr. R. H. 